\title{
RESULTS OF GENOTYPING HEPATITIS VIRUS B IN HBSAg-NEGATIVE BLOOD DONORS IN ASTANA, KAZAKHSTAN
}

\author{
Yu.V. Ostankova ${ }^{a}$, A.V. Semenov ${ }^{\mathrm{a}, b, c}$, Z.K. Burkitbayev', T.N. Savchuk ${ }^{\mathrm{d}}$, Areg A. Totolian ${ }^{\mathrm{a}, \mathrm{b}}$ \\ ${ }^{a}$ St. Petersburg Pasteur Institute, St. Petersburg, Russian Federation \\ ${ }^{b}$ Pavlov First St. Petersburg State Medical University, St. Petersburg, Russian Federation \\ ${ }^{c}$ North-Western State Medical University named after I.I. Mechnikov, St. Petersburg, Russian Federation \\ ${ }^{d}$ Research and Production Center of Transfusiology, Astana, Kazakhstan
}

\begin{abstract}
The prevalence of HBV infection is estimated by the frequency of occurrence of HBsAg and varies depending on the geographic region. Chronic infection is characterized by a stable presence of HBsAg for 6 months, with the exception of the occult form of the disease, characterized by the absence of HBsAg, an extremely low level of HBV DNA in the blood serum. The problem of identifying occult HBV (ocHBV) is especially relevant because of the development of transplantology and transfusiology. However, serological screening of donor blood used in the Russian Federation and Central Asian countries does not reveal HBV seronegative donors. Since HBV infection is possible with the introduction of small doses of the virus, the importance of using complex molecular methods for detecting donor ocHBV is obvious, despite the low viral load, since donor blood is used predominantly in patients with severe course of various diseases characterized by increased susceptibility to $\mathrm{HBV}$ because of immunosuppression. The aim of our work was to study the characteristics of the genetic structure of the ocHBV in donors in Astana, Kazakhstan. A total of 500 blood plasma samples from HBsAg-negative donors were obtained in 2012 from residents of Kazakhstan, Astana. Using the method, we proposed to detect HBV DNA with a low viral load, HBV was detected in $9.4 \%$ of donors. Serological markers were found in $12.7 \%$ of patients with HBV DNA, $8.5 \%$ had HBcor IgG antibodies, 4.2\% had HBcor IgG and HBe IgG antibodies at the same time. Thus, in 41 (87.3\%) of the blood donor, ocHBV was seronegative. Based on the phylogenetic analysis of the 47 isolates showed that the HBV of genotype $\mathrm{D}(95.75 \%)$ prevails in the examined group in comparison with $\mathrm{HBV}$ of genotype $\mathrm{A}(4.25 \%)$. HBV subgenotypes are represented in the following ratios: D1 - 46.8\%, D2 - 17.05\%, D3 - 31.9\%, A2 - 4.25\%. In a comparative analysis, the distribution of HBV subgenotypes in the group with ocHBV and in the case of the manifest form in donors in the Republic of Kazakhstan significantly differed $\chi^{2}=14.027$ at $p=0.0072, \mathrm{~d}_{\mathrm{f}}=4$. The incidence of HBV D3 with ocHBV (31.9\%) exceeded that of patients with a manifest form (7.4\%). The relative risk of occult form of disease in patients with the subgenotype D3 is significantly higher $(\mathrm{RR}=1.572$, CI: $1.179-2.096, p=0.0208$ ). When assessing the picture of HBV diversity on the material of the group including HBsAg-negative and HBsAg-positive blood donors, it is evident that the genetic relationship of the manifestations of the manifest $\mathrm{HBV}$ and the ocHBV of genotype $\mathrm{D}$ is obvious. Among the isolates are both similar in nucleotide sequences with those previously described in various regions of Europe and Central Asia, and circulating in the territory of the Republic of Kazakhstan, which indicates an independent homologous evolution of $\mathrm{HBV}$ in the region. The high incidence of ocHBV among HBsAg-negative blood donors is indicative not only of the widespread prevalence of the occult form of the disease course in the population and the inadequacy for the detection of chronic HBV of conventional HBsAg and HBV DNA in the peripheral blood using commercial kits, but also the need to study the characteristics of the immune response with this form of the disease course.
\end{abstract}

Key words: hepatitis $B$, occult $H B V$, molecular epidemiology, DNA HBV.

\author{
Адрес для переписки: \\ Останкова Юлия Владимировна \\ 197101, Россия, Санкт-Петербург, ул. Мира, 14, \\ ФБУН НИИ эпидемиологии и микробиологии имени Пастера. \\ Тел.: 8 (812) 233-20-92 (служебн.). \\ E-mail: shenna1@yandex.ru
}

\section{Библиографическое описание:}

Останкова Ю.В., Семенов А.В., Буркитбаев Ж.К., Савчук Т.Н.,

Тотолян Арег А. Результаты генотипирования вируса гепатита

в у HBsAg-негативных доноров крови в г. Астана, Казахстан // Инфекция

и иммунитет. 2017. Т. 7, № 4. С. 383-392. doi: 10.15789/2220-7619-2017-

4-383-392

(C) Ostankova Yu.V. et al., 2017

\section{Contacts:}

Julia V. Ostankova

197101, Russian Federation, St. Petersburg, Mira str., 14,

St. Petersburg Pasteur Institute.

Phone: +7 (812) 233-20-92 (office).

E-mail: shenna1@yandex.ru

\section{Citation:}

Ostankova Yu.V., Semenov A.V., Burkitbayev Z.K., Savchuk T.N., Totolian Areg A. Results of genotyping hepatitis virus B in HBsAg-negative blood donors in Astana, Kazakhstan // Russian Journal of Infection and Immunity = Infektsiya i immunitet, 2017, vol. 7, no. 4, pp. 383-392. doi: 10.15789/2220-7619-2017-4-383-392

DOI: http://dx.doi.org/10.15789/2220-7619-2017-4-383-392 


\title{
РЕЗУЛЬТАТЫ ГЕНОТИПИРОВАНИЯ ВИРУСА ГЕПАТИТА В У НВsАg-НЕГАТИВНЫХ ДОНОРОВ КРОВИ В г. АСТАНА, КАЗАХСТАН
}

\author{
Ю.В. Останкова ${ }^{1}$, А.В. Семенов ${ }^{1,2,3}$, Ж.К. Буркитбаев ${ }^{4}$, Т.Н. Савчук ${ }^{4}$, Арег А. Тотолян ${ }^{1,2}$ \\ ${ }^{1}$ ФБУН Санкт-Петербургский НИИ эпидемиологии и микробиологии имени Пастера, Санкт-Петербург, Россия \\ ${ }^{2}$ ГБОУ ВПО Санкт-Петербургский государственный медицинский университет имени академика И.П. Павлова \\ МЗ РФ, Санкт-Петербург, Россия \\ ${ }^{3}$ ГБОУ ВПО «Северо-Западный государственный медицинский университет им. И. И. Мечникова» МЗ РФ, \\ Санкт-Петербург, Россия \\ ${ }^{4}$ Научно-производственный центр трансфузиологии, Астана, Казахстан
}

Резюме. Распространенность ВГВ-инфекции оценивается по частоте встречаемости НВsAg и варьирует в зависимости от географического региона. Для хронической инфекции характерно устойчивое присутствие $\mathrm{HBs} A \mathrm{~g}$ в течение 6 месяцев за исключением оккультной формы течения заболевания, характеризующейся отсутствием HBsAg, крайне низким уровнем ДНК ВГВ в сыворотке крови. Проблема выявления оккультного ГВ (окГВ) особенно актуальна в связи с развитием трансплантологии и трансфузиологии. Однако использующийся в РФ и странах Средней Азии серологический скрининг донорской крови не выявляет ВГВ серонегативных доноров. Поскольку заражение ВГВ возможно при введении малых доз вируса, очевидна значимость использования сложных молекулярных методов для выявления окГВ у доноров, несмотря на низкую вирусную нагрузку, так как донорская кровь используется преимущественно у пациентов с тяжелым течением различных заболеваний, отличающихся повышенной восприимчивостью к ВГВ на фоне иммуносупрессии. Целью нашей работы было изучение особенностей генетической структуры окГВ у доноров крови в г. Астана, Казахстан. Обследовано 500 HBsAg-негативных образцов плазмы донорской крови, полученные в 2012 г. от жителей Казахстана, г. Астана. При использовании предложенного нами метода выявления ДНК ВГВ при низкой вирусной нагрузке ВГВ был выявлен у 9,4\% доноров. Серологические маркеры обнаружены у 12,7\% пациентов с выявленной ДНК ВГВ, при этом в 8,5\% случаев обнаружены антитела HBcor IgG, в 4,2\% случаев антитела HBcor IgG и HBe IgG одновременно. Таким образом, у 41 (87,3\%) донора крови окГВ был в серонегативной форме. На основании филогенетического анализа 47 изолятов показано, что в обследованной группе преобладает ВГВ генотипа D $(95,75 \%)$ по сравнению с ВГВ генотипа А (4,25\%). Субгенотипы ВГВ представлены в следующих соотношениях: D1 - 46,8\%, D2 - 17,05\%, D3 - 31,9\%, A2 - 4,25\%. При сравнительном анализе распределение субгенотипов ВГВ в группе с окГВ и при манифестной форме у доноров в Республике Казахстан достоверно отличалось $-\chi^{2}=14,027$ при $\mathrm{p}=0,0072, \mathrm{~d}_{\mathrm{f}}=4$. Частота встречаемости ВГВ D3 при окГВ $(31,9 \%)$ превышала таковую у пациентов с манифестной формой $(7,4 \%)$. Относительный риск развития оккультной формы ХВГВ у пациентов с субгенотипом D3 достоверно выше $(\mathrm{RR}=$ 1,572, CI: 1,179-2,096, p = 0,0208). При оценке картины разнообразия ВГВ на материале группы, включающей HBsAg-негативных и HBsAg-позитивных доноров крови становится очевидным близкое генетическое родство изолятов манифестного ХВГВ и окГВ генотипа D. Среди изолятов представлены как сходные по нуклеотидным последовательностям с ранее описанными в различных регионах Европы и Средней Азии, так и циркулирующие на территории Республики Казахстан, что свидетельствует о независимой гомологичной эволюции ВГВ в регионе. Высокая встречаемость окГВ среди HBsAg-негативных доноров крови свидетельствует не только о широком распространении оккультной формы течения заболевания в популяции и недостаточности для выявления ХВГВ общепринятых анализов на HBsAg и ДНК ВГВ в периферической крови с использования коммерческих наборов, но и говорит о необходимости изучения особенностей иммунного ответа при данной форме течения ХВГВ.

Ключевые слова: гепатит В, оккультный ВГВ, молекулярная эпидемиология, секвенирование.

\section{Introduction}

According to the World Health Organisation (WHO), in the world there are almost 2 billion people infected with the hepatitis B virus (HBV), more than 240 million develop chronic viral hepatitis B (CHBV) - a diffuse inflammatory disease associated with persistence of HBV [47]. Annually, 686000 people die from hepatitis B infection, as well as from liver cirrhosis and cancer as a result of chronic infection complications [19]. The widespread prevalence of HBV remains a major global health problem.

The prevalence of HBV infection at this time is estimated by the frequency of occurrence of HB$\mathrm{sAg}$ and varies depending on the geographic region.
The prevalence is classified as high ( $\geq 8 \%$ of the population), medium (2-7\% of the population) and low $(<2 \%$ of the population) [28]. In the Russian Federation, as well as in the territory of the former Soviet Union, the average incidence of $\mathrm{HBV}$ is about 5\% [9].

Phylogenic analysis of complete nucleotide sequences obtained from different regions of the world has made it possible to divide HBV into ten genotypes, designated as A-J genotypes, differing in the composition of nucleotide sequences by more than $8 \%$; as well as by 35 subgenotypes (within the genotypes A, B, C, D, F, H), for which the discrepancy between complete nucleotide sequences makes $4-7.5 \%$ [11, 24, 25, 27, 31, 33, 48]. 
Studies of the prevalence of HBV genovariants in different regions of the world have been actively conducted since genotypes were discovered to the present. Genotypes are distributed geographically. This distribution varies very slowly over time, reflecting the ways in which the virus spreads due to human migration, as well as the peculiarities of the geographical origin of different genotypes. This allows to use HBV genovariants as epidemiological markers [24]. In most regions, with rare exception, the circulate genotypes make up 1 or 2 prevailing and several minor ones, including those imported from other territories [31]. The country prevailing HBV genotypes depend significantly on the migration of the population and the origin of immigrants. That is, the ways of spreading the virus in connection with population migration as well as its origin can be traced through the heterogeneity of genotypes distribution in various regions of the world.

Although, using an effective HBV vaccine in clinical practice has significantly reduced the circulation of the virus, there is a tendency observed in recent years - a shift of the prevalence of HBV genotypes in various geographic areas due to migration from countries with a high incidence of hepatotropic viruses. This forces physicians and epidemiologists to pay close attention to the epidemiological situation in neighboring countries [15]. This is especially relevant in the light of active migration processes involving the population of the Russian Federation and the countries of the Central Asian region, where the prevalence of $\mathrm{HBV}$ is high.

Chronic HBV infection occurs in $90 \%$ of children infected in the pre- and neonatal period, $25-50 \%$ of children infected at $1-5$ years of age, $1-5 \%$ of people infected as older children and up to $10 \%$ got infected being adults [13, 21, 29, 41, 49].

The clinical manifestations of CHBV are diverse and depend mainly on the biological properties of the virus and its interaction with the host's immune system. However, the duration of the disease, the level of viral load and its changes over time, virus mutations, environmental and genetic factors, ethnicity and sex of the patient can influence the course of the disease [12]. Chronic infection is characterized by a stable presence of HBsAg for at least 6 months (with or without $\mathrm{HBeAg}$ concomitant), with the exception of the occult form of the disease characterized by the absence of HBsAg, an extremely low level of HBV DNA in the blood serum $(<200$ IU of HBV DNA per ml) [39].

Due to the relatively recent discovery of this variant of $\mathrm{CHBV}$, the risk factors associated with occult infection of CHBV are still not fully investigated and understood, although some data suggest that occult $\mathrm{HB}(\mathrm{OHB})$ retains most of the same risk factors as the symptomatic form of CHBV [36]. The problem of $\mathrm{OHB}$ has become especially important in connection with the development of transplantology and transfusiology, as well as in connection with new data concerning the importance of HBV infection with low viral load (low dose infection was used as an analogue) for the development of instant seronegative OHB and a high risk of hepatocellular carcinoma [30].

Ensuring the infectious safety of blood transfusions during planned and urgent surgical operations is a topical medical problem and should be implemented first of all in order to prevent the transmission of viruses. Post-transfusion infection of HBV is a serious problem and is one of the significant risk factors for human infection. It is reported that the risk of $\mathrm{HBV}$ infection after transfusion is higher than that of other blood-borne viruses, such as HIV and $\mathrm{HCV}$ [22]. Including because in connection with the use of standard commercial kits, the OHB can later be detected in persons negative for all $\mathrm{HBV}$ markers [17].

At the heart of viral blood safety in transfusiology is the quality of donor selection and testing for markers of viral infections. For serological screening of donor blood in the Russian Federation, test systems are used to detect $\mathrm{HBsAg}$, which, of course, cannot ensure the absolute detection of infected donors. The criteria and protocol adopted in the serological screening of blood donors in Russia and Central Asia significantly reduced the likelihood of HBV transmission. In an ideal situation, which the blood transfusion centers seek, in donors, especially in regular donors, there should be no infections. However, at present comparison of the incidence of infections in donors and in the population serves as a tool for assessing the quality of donor selection [1, 2]. Despite the introduction of universal vaccination and the development of sensitive and specific assays that in recent decades have reduced the risk of infection, HBV seronegative donors may still transmit the virus in the late phase of infection [38].

It is extremely important to determine the prevalence of OHB among healthy blood donors to assess the likelihood of transmission of HBV through blood transfusion, and then assess the need to improve and even modify donor pre-selection strategies to reduce the risk of transmission [18]. Therefore, molecular methods have been used for several years for the selection of a donor blood in the United States and a number of European countries. Since, as mentioned above, HBV infection is possible with the introduction of small doses of the virus, it is evident that the complex molecular methods for the detection of OHB in donors are very important, despite the extremely low viral load in these samples. When screening donors blood, this is especially important, since donor blood is used mainly in patients with severe course of various diseases characterized by increased susceptibility to HBV against immunosuppression. The importance of detecting $\mathrm{OHB}$ in the population and in blood donors was also shown in the study 
of a specific immune response, where the severity of the Th1 response in patients with OHB was significantly higher than in patients with symptomatic CHBV in the phase of inactive HBV carrier [14, 50].

The purpose of this paper is to study the peculiarities of the genetic structure of $\mathrm{OHB}$ in blood donors in Astana, Kazakhstan.

\section{Materials and methods}

The work used 500 samples of donor blood plasma, obtained in 2012 from residents of Kazakhstan, Astana. A sample of blood from each donation was examined for the markers of four blood-borne infections: HIV (p24 HIV-1 antigen and anti-HIV-1/2 antibodies), HBV (HBV surface antigen, HBsAg), HCV (anti-HCV antibodies); syphilis (class M and G anti-Treponema pallidum antibodies).

Primary detection of $\mathrm{HBV}$ was carried out by isolating nucleic acids (NK) from the blood plasma using the «AmplePrime Ribo-prep» commercial kit (FBIS CRIE, Moscow). For all samples, preliminary concentration of virus particles was carried out by ultracentrifugation of blood plasma for 1 hour at $24000 \mathrm{~g},+4^{\circ} \mathrm{C}$. Analysis of the presence of the virus was carried out by polymerase chain reaction (PCR) with hybridization-fluorescent detection in real time mode using the «AmpliSens ${ }^{\circledR} \mathrm{HBV}-\mathrm{FL}$ » commercial kit (FBIS CRIE, Moscow).

Later, a technique developed in the St. Petersburg Pasteur Institute was used to detect HBV in biological material with low viral load. The following composition of the amplification mixture for PCR was generally used: $15 \mathrm{pM}$ of each oligoprimers, $1.0 \mathrm{mM}$ of each nucleoside triphosphate, $6.7 \mathrm{mM}$ $\mathrm{MgCl}_{2}, 1$ unit of recombinant Taq DNA polymerase (Fermentas), buffer for Taq DNA polymerase (750 mM Tris-HCl, (pH 8.8), $200 \mathrm{mM}$ (NH4) 2 $\mathrm{SO}_{4}$, $0.1 \%$ (v/v) Tween 20), 10\% DMSO, $1 \mu \mathrm{g}$ matrix, water without nucleases to a final volume of $25 \mu 1$. Amplification in general was carried out under the following conditions: after denaturation at $95^{\circ} \mathrm{C}$ for $5 \mathrm{~min}, 30-40$ amplification cycles were set in the mode: $95^{\circ} \mathrm{C}-20-40 \mathrm{sec}, 55-65^{\circ} \mathrm{C}-20-30 \mathrm{sec}$, $72^{\circ} \mathrm{C}-30-90 \mathrm{sec}$; then the final elongation at $72^{\circ} \mathrm{C}-5 \mathrm{~min}$. The quality of the PCR was determined visually in a $2 \%$ agarose gel $(120 \mathrm{~V}, 40 \mathrm{~min}$, 1xTBE) stained with ethidium bromide. Specific primers (Syntol, Russia) were used for the amplification and sequencing reaction, the sequence of which was taken from literary sources and were also selected using the NCBI/Primer-BLAST program according to generally accepted recommendations. Overlapping primer pairs were used, jointly flanking 1475 base pairs (bp) fragment, including the recommended for HBV genotyping the 1169 bp Pre-S1/Pre$\mathrm{S} 2 / \mathrm{S}$ area of 2848-3182...1-835 nucleotides, according to the Mart-B47 isolate (HE974377.1) presented in the international GenBank database [16].
The sequencing reaction was carried out according to the instructions to the reagent kit ABI PRISM $^{\circledR}$ BigDye $^{\mathrm{TM}}$ Terminator v3.1. (Applied Biosystems, USA), in triplicate, on forward and reverse primers. The reaction mixture for the sequencing reaction comprised: ABI PRISM ${ }^{\circledR}$ BigDye $^{\mathrm{TM}}$ Terminator v3.1 Kit $4 \mu \mathrm{l}$, primer for sequencing $3.0 \mu \mathrm{l}$ (concentration of $1.6 \mu \mathrm{mol} / \mu \mathrm{l})$, purified amplification product (volume depended on concentration), deionized water to a final volume of the mixture of $20 \mu \mathrm{l}$. The reaction was performed on a BIO-RAD CFX96 thermocycler in the mode of 25 amplification cycles were set at $96^{\circ} \mathrm{C}$ for $10 \mathrm{sec}$, at $50^{\circ} \mathrm{C}$ for $5 \mathrm{sec}$, and at $60^{\circ} \mathrm{C}$ for $4 \mathrm{~min}$.

Primary amplification and sequencing reactions products were purified according to the following procedure: a mixture of $2 \mu \mathrm{l}$ of $3 \mathrm{M}$ sodium acetate, $2 \mu \mathrm{l}$ of $0.125 \mathrm{M}$ EDTA and $1 \mu \mathrm{l}$ of glycogen were added to $20 \mu 1$ of the amplification product and incubated at room temperature in the presence of a cooled $96 \%$ ethyl alcohol for $15 \mathrm{~min}$. Centrifuged at $14000 \mathrm{rpm}$, $4^{\circ} \mathrm{C}$ for $15 \mathrm{~min}$. The supernatant was removed and the precipitate was washed twice with chilled $70 \%$ ethyl alcohol, repeating the cold centrifugation procedure. The washed residue was dried.

A purified fragment of sufficient concentration was used for setting up sequencing reactions.

To analyze the product of the sequencing reaction, the purified residue was denatured in formamide and placed in the ABI Prism 3500 genetic analyzer (Applied Biosystems, USA).

The initial analysis of the fragments obtained during the sequencing was performed using the NCBI Blast program in comparison with the nucleotide sequences presented in the international GenBank database. Alignment of nucleotide sequences was carried out in the MEGA 7.0 program using the ClustalW algorithm [45]. Since for all the regions of viral hepatitis selected for sequencing, a high evolution rate is shown, for the construction of phylogenetic trees and subsequent phylogenetic analysis, considered the distances between sequences by the Neighborjoining method, which allows the optimization of the tree in accordance with the criterion of "balanced minimum evolution", and bootstrap analysis for 500 repetitions was carried out in order to evaluate the reliability of the constructed trees [26].

\section{Results and discussion}

In Kazakhstan, in 2007, according to WHO, the incidence of hepatitis $\mathrm{B}$ exceeded $8 \%$, and antibodies to $\mathrm{HBcor}$ were found in $30 \%$ of the population [32]. To date, the epidemiological situation of viral hepatitis remains tense. While in Central Kazakhstan the incidence of OHB was significantly reduced [7], in South Kazakhstan there was a tendency of increased incidence of chronic viral hepatitis, first detected [5]. 
In our study, in the group of $\mathrm{HBsAg-negative}$ blood donors, HBV DNA could not be detected using the «AmpliSens ${ }^{\circledR}$ HBV-FL» commercial kit (FBIS CRIE, Moscow). Using our method of detecting HBV DNA at low viral load, HBV was detected in 47 (9.4\%) donors. With further sequencing of the samples, their genetic individuality was shown, which was confirmed by the diversity between the nucleotide sequences, which additionally indicates the validity of the detected cases of $\mathrm{OHB}$ in blood donors.

It is known, depending on a number of factors (transferred diseases, operations, vaccinations, increased ALAT activity, etc.), a person may be not allowed to give blood temporarily (temporary withdrawal from donation) or permanently (permanent withdrawal from donation). Among donors who had HBV DNA detected, there were $14.9 \%$ who performed blood or plasma donation once, including two withdrawal cases; $19.1 \%$ who performed blood or plasma donation twice, no withdrawal cases; $38.3 \%$, who performed blood or plasma donation 3-7 times, 4 withdrawal cases, two of which are associated with an elevated level of ALAT; $27.7 \%$ who performed blood or plasma donation more than 10 times (12117 times), all donors except one had withdrawal cases 1 to 9 times, while two donors had 1 withdrawal case, associated with the HBsAg repeated analysis, in seven donors, one or more withdrawal cases were associated with elevated ALAT levels.

Serological markers were detected in $6(12.7 \%)$ patients with HBV DNA, 4 (8.5\%) cases with detected HBcor IgG antibodies, 2 (4.2\%) cases with detected $\mathrm{HBcor}$ IgG and $\mathrm{HBe}$ IgG antibodies. Thus, in $41(87.3 \%)$ of the blood donor, OHB was in seronegative form.

For all the samples identified, a nucleotide sequence of Pre-S1/Pre-S2/S area of adequate quality, suitable for further analysis, was obtained. For all samples, the genotype and subgenotype of the virus were determined. Based on the phylogenetic analysis of 47 isolates, it was shown that HBV of genotype D $(95.75 \%)$ prevails in the examined group and only two patients with HBV genotype A (4.25\%) are represented. Among the patients with HBV genotype D, the highest frequency was found in the subgenotype D1 (48.9\%) in comparison with the subgenotypes D2 (17.8\%) and D3 (33.3\%). Thus, among the 47 samples of $\mathrm{OHB}$ in HBsAg-negative blood donors were subgenotypes of $\mathrm{HBV}$ in the following ratios: D1 - 46.8\%, D2 - 17.05\%, D3 - 31.9\%, A $2-4.25 \%$, respectively. The intra-group percentage of nucleotide identity among blood donors with HBV subgenotypes D1, D2 and D3 was $98.05 \pm 0.7 \%$, $99.1 \pm 0.35 \%$ and $98.9 \pm 0.45 \%$, respectively. Phylogenetic relationships between the studied isolates of $\mathrm{OHB}$ obtained from blood donors from the Republic of Kazakhstan and reference sequences from the international GenBank database are presented in Figure.
It is known that in most of the territory of the former USSR and in the countries of the Baltic region, HBV subgenotype D2 prevails, the subgenotypes A2 and D3 [46] are present, while for the countries of Central Asia the distribution of the HBV subgenotypes shifts towards the predominance of the subgenotype D1. Thus, the high occurrence of the subgenotype D1 corresponds to the previously obtained data on the molecular genetic characteristics of HBV in Central Asia, however, the increased incidence of HBV D2 and D3 is noteworthy.

According to the presented dendrogram, among the isolates D1 there are two subclasses of HBV circulating, most likely, in the territory of the Republic of Kazakhstan, as well as several independent isolates similar in nucleotide sequences with those previously described. Among the D2 isolates, one HBV subcluster and also several independent isolates are determined. Among HBV D3, it is evident that there is a division into two subclusters, which have a high similarity with those previously described in Europe. Thus, HBV in the subgroups represented, apparently, has several independent sources of infection. The high similarity of isolates with the samples from different countries described in the international database is, apparently, the confirmation of numerous independent importations of the virus into the country, including during large migration waves. The identification of subclusters, which have much less similarity to the isolates previously deposited in the database, indicates an independent homologous evolution of $\mathrm{HBV}$ in the region.

In the group of blood donors we examined, there were more men than women -76.8 and $23.2 \%$, respectively. In the analysis of the occurrence of HBV in the group, there were no significant differences $(\mathrm{p}=$ 0.3652 ), depending on gender, but there was a trend towards more frequent infection of men $(10.1 \%)$ than women $(6.9 \%)$. In the analysis of the distribution of HBV subgenotypes by gender, the subgenotype D1 (75\%) prevailed in women compared to D2 and D3 (12.5\%); men also had a more frequent subgenotype D1 (41.1\%) compared to D2 (17.9\%), D3 (35.9\%) and A2 $(5.1 \%)$, but no significant differences were found between the groups. Nevertheless, there is a trend towards a high incidence of the subgenotype D3 in men in this group. The average age in the group of blood donors we examined was $30.5 \pm 9.8$ years. The average age of donors with detected HBV DNA was 28.2 \pm 8.8 years, with the number of donors with $\mathrm{OHB}$ less than 20 y.o. being $8.5 \%$, at the age of $20-30$ years $-55.3 \%$, at the age of $30-40$ years $-23.4 \%, 40+$ years $12.8 \%$. Thus, among the donors of blood with $\mathrm{OHB}$ a large proportion of detected HBV $(78.7 \%)$ fell on the age group with high sexual activity. Differences in the distribution of HBV subgenotypes, depending on the age of the patient, have not been revealed.

Earlier, we reported on the analysis of genetic variants of $\mathrm{HBV}$ in $\mathrm{HBsAg}$-positive primary donors in the Republic of Kazakhstan. HBV subgenotype 


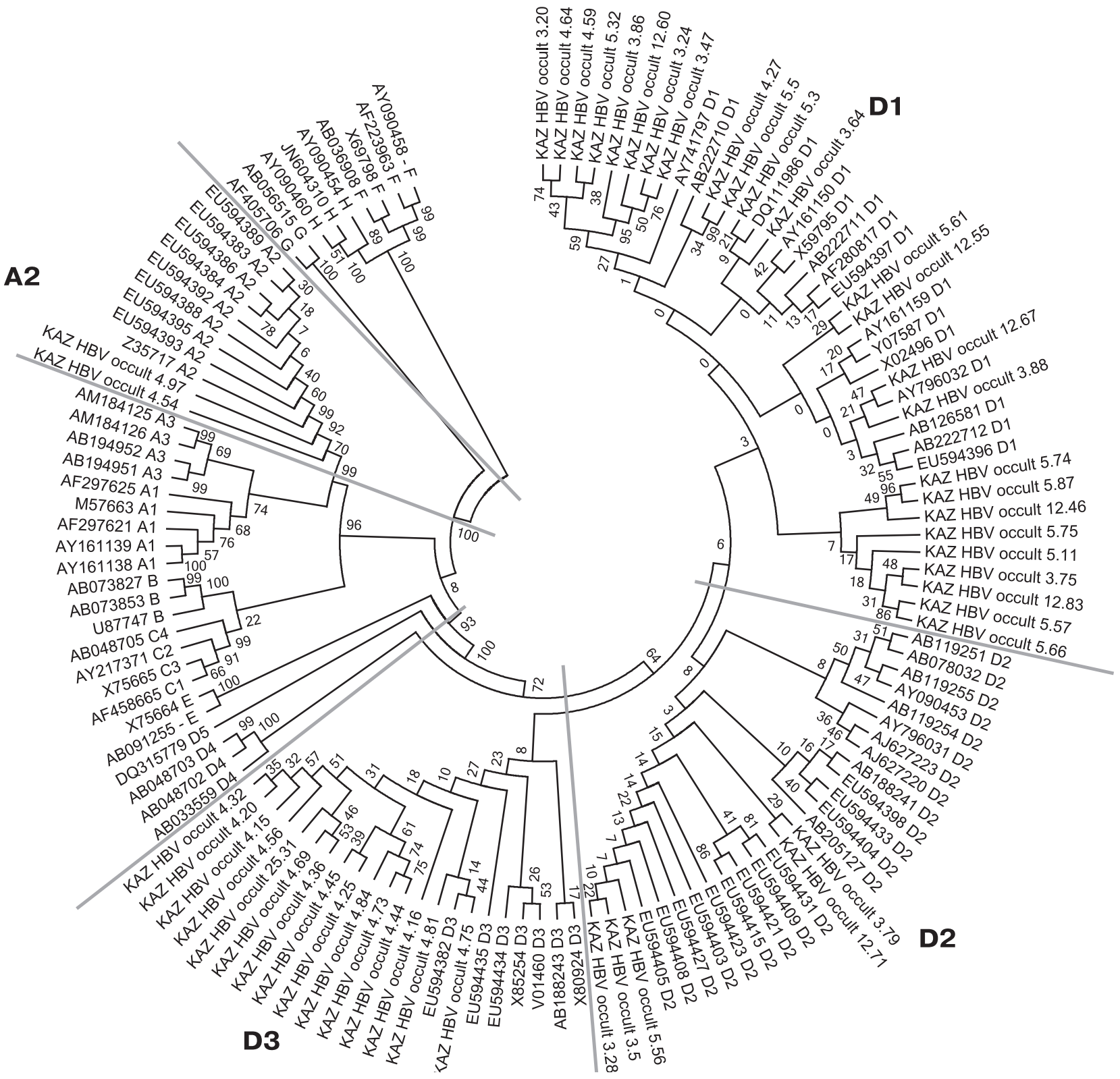

Figure. Dendrogram characterizing the phylogenetic relationships of HBV isolates obtained from blood donors from the Republic of Kazakhstan, in comparison with the reference sequences presented in the international GenBank database

D1 $(85.2 \%)$ prevailed compared to HBV subgenotype D2 $(3.7 \%)$ and subgenotype D3 (7.4\%), one sample revealed an HBV genotype A subgenotype A1 (3.7\%) [3]. Using a comparative analysis, the distribution of HBV subgenotypes in the group with $\mathrm{OHB}$ and in the symptomatic form of the disease in donors in the Republic of Kazakhstan significantly differed $-\chi^{2}=14.027$ at $p=0.0072, \mathrm{~d}_{\mathrm{f}}=4$. The incidence of HBV D3 with OHB (31.9\%) was significantly higher than that of patients with a symptomatic form (7.4\%). At the same time, the relative risk of development of occult form CHBV in patients with the subgenotype D3 is significantly higher $(\mathrm{RR}=1.572, \mathrm{CI}$ : $1.179-2.096, \mathrm{p}=0.0208)$. It should be noted that the data obtained on the distribution of HBV sub- genotypes among patients with $\mathrm{OHB}$ also differ from the distribution of HBV subgenotypes in the symptomatic form of the disease in such nearby countries of Central Asia as Uzbekistan (D1 $=80.95 \%$, D2 = $4.75 \%$ D3 - 14.3\%) and Kyrgyzstan (D1 - 68.75\%, D2 - $18.75 \%$, D3 - 12.3\%) [4, 6].

It can be assumed that the high incidence of $\mathrm{HBV}$ D3 in HBsAg-negative blood donors is related to the course of the disease, but it should be noted that the prevalence of D3 isolates in Astana was, according to the published data, rather high and amounted to $20.4 \%$ [8]. We assume that the relatively high frequency of occurrence of the subgenotypes D2 and D3 and the predominant detection of OHB in the sexually active age group are interrelated. 
An indirect confirmation of our assumption is the work that showed the prevalence of HBV D2 and D3 in patients who recognized risky sexual behavior, while a group of patients who claimed to have been infected by surgery or blood transfusion shown many subgenotypes. This may be due to the fact that patients who underwent surgery and blood transfusion were exposed to several sources of infection [40].

The prevalence of OHB in different geographic regions differs, but mainly correlates with prevalence of the symptomatic HBV in the region. However, the data on the study of blood donors, stem cells, and organs for the presence of OHB are little and contradictory. For example, among blood donors in Argentina $(\mathrm{n}=70102)$, HBV was detected in only $0.06 \%$ of the samples, of which only four were OHB [35]. In the Lao People's Democratic Republic, the preva-

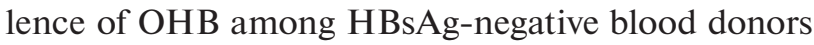
was $10.9 \%$ [23]. In Nigeria, the incidence of OHB among blood donors reached 17\% [35]. In the analysis of healthy stem cell donors from South Korea, OHB was detected in $15.3 \%$, which, like in the case of a significant occurrence of OHB in the population, can be explained by the high prevalence of hepatotropic viruses in this geographic region [20]. In Indonesia, occult HBV was detected in $8.1 \%$ of blood donors [44]. In Iran, since the routine neonatal vaccination against HBV was adoption in 1993, the prevalence of the virus was about $1.7 \%$ [37]. Nevertheless, the general data vary depending on the methods of virus definition, including the variety of commercial kits for detecting HBsAg and HBV DNA, and the reported prevalence of $\mathrm{OHB}$, especially among healthy blood donors, varies. For example, the prevalence of HBsAg in the Iranian population and in blood donors is $2.6 \%$ and $0.4 \%$, respectively, while the prevalence of OHB among blood donors was estimated to be slightly more than $4 \%[10,42,46]$.
Data on the prevalence of OHB in the population of the Republic of Kazakhstan could not be found, but it can be assumed that with such a high prevalence among blood donors, in the population, the OHB can also be widely spread. When assessing the HBV diversity using the material of the entire surveyed group, including $\mathrm{HBsAg}$-negative and HBsAg-positive blood donors, the close genetic relationship of the isolates of the symptomatic CHBV and the OHB genotype D becomes evident, which also indicates the prevalence of $\mathrm{OHB}$ in the region.

\section{Conclusion}

Detection of HBV DNA is a complex task for effective laboratory diagnosis of hepatitis, especially where PCR is not accepted as one of the screening methods for detecting $\mathrm{HBV}$, which is important for highly endemic viral hepatitis regions.

The high incidence of OHB among HBsAg-negative blood donors is indicative not only of the widespread prevalence of the occult form of the disease course in the population and the failure to detect HBV of conventional HBsAg and HBV DNA assays in the peripheral blood using commercial kits, but also the need to study the features of the immune response with a given form of the disease course of CHBV.

Despite the fact that the best international standards for screening donor blood for markers of transfusion infections have been introduced in Kazakhstan, the systematic application of molecular phylogenetics in the analysis of OHB in blood donors can contribute to an understanding of the epidemiology of the infectious process, the identification of the features of the spread and the role of "imported" HBV genotypes in the circulation of the virus in the region.

\section{Список литературы/References}

1. Вирусные гепатиты в Российской Федерации: аналитический обзор. СПб: ФБУН НИИЭМ имени Пастера, 2016.152 с. [Virusnye gepatity v Rossiiskoi Federatsii: analiticheskii obzor [Viral hepatitis in the Russian Federation: an analytical review]. St. Petersburg: St. Petersburg Pasteur Instutute, 2016. 152 p.]

2. Жибурт Е.Б., Губанова М.Н., Скорикова С.В., Буркитбаев Ж.К., Шестаков Е.А., Мамадалиев Д.М., Мадзаев С.Р. Новое в трансфузиологии (на конгрессах Международного общества переливания крови в Канкуне и Куала-Лумпуре) // Трансфузиология. 2014. T. 15, № 3. С. 44-60. [Zhiburt E.B., Gubanova M.N., Skorikova S.V., Burkitbaev Z.K., Shestakov E.A., Mamadaliev D.M., Madzaev S.R. News in transfusion medicine (at congresses of the international society of blood transfusion in Cancun and Kuala-Lumpur). Transfuziologiya = Transfusiology, 2014, vol. 15, no. 3, pp. 44-60. (In Russ.)]

3. Жибурт Е.Б., Мадзаев С.Р., Шестаков Е.А., Вергопуло А.А. Менеджмент крови пациента. М.: Национальный медикохирургический центр имени Н.И. Пирогова, 2014. 64 с. [Zhiburt E.B., Madzayev S.R., Shestakov E.A., Vergopulo A.A. Menedzhment krovi patsienta [Blood management of the patient]. Moscow: National Pirogov Medical and Surgical Center, 2014. 64 p. (In Russ.)]

4. Останкова Ю.В., Семенов А.В., Буркитбаев Ж.К., Савчук Т.Н., Тотолян А.А. Генетические варианты вируса гепатита В у первичных доноров в г. Астана, Казахстан // Инфекция и иммунитет. 2016. T. 6, № 4. С. 359-365. [Ostankova Yu.V., Semenov A.V., Burkitbayev Z.K., Savchuk T.N., Totolian A.A. Genetic variants of hepatitis B virus in primary donors in Astana, Kazakhstan. Infektsiya i immunitet $=$ Russian Journal of Infection and Immunity, 2016, vol. 6, no. 4, pp. 359-365. doi: 10.15789/22207619-2016-4-359-365 (In Russ.)] 
5. Останкова Ю.В., Семенов А.В., Файзуллаев Х.Н., Казакова Е.И., Козлов А.В., Мусабаев Э.И., Тотолян А.А. Молекулярно-биологические маркеры гепатита В у пациентов с фиброзом/циррозом печени в Узбекистане // Журнал микробиологии, эпидемиологии и иммунобиологии. 2016. № 5. C. 34-43. [Ostankova Yu.V., Semenov A.V., Faizullaev Kh.N., Kazakova E.I., Kozlov A.V., Musabaev E.I., Totolyan A.A. Molecular-biological markers of hepatitis B in patients with liver fibrosis/cirrhosis in Uzbekistan. Zhurnal mikrobiologii, epidemiologii i immunobiologii = Journal of Microbiology Epidemiology and Immunobiology, 2016, no. 5, pp. 34-43. (In Russ.)]

6. Полукчи Т.В., Абуова Г.Н., Батырханова С.Т. Состояние заболеваемости острыми и хроническими вирусными гепатитами в Южно-Казахстанской области // Международный студенческий научный вестник. 2016. № 4. С. 39-40. [Polukchy T.V., Abuova G.N., Batyrkhanova S.T. The incidence of acute and chronic viral hepatitis in the South Kazakhstan region. Mezhdunarodnyi studencheskii nauchnyi vestnik = International Student Scientific Bulletin, 2016, no. 4, pp. 39-40. (In Russ.)]

7. Семенов А.В., Останкова Ю.В., Ногойбаева К.А., Касымбекова К.Т., Лаврентьева И.Н., Тобокалова С.Т., Тотолян А.А. Особенности молекулярной эпидемиологии сочетанной инфекции ВГВ/ВГD в Кыргызстане // Инфекция и иммунитет. 2016. T. 6, № 2. C. 141-150. [Semenov A.V., Ostankova Y.V., Nogoybaeva K.A., Kasymbekova K.T., Lavrentieva I.N., Tobokalova S.T., Totolyan A.A. Molecular epidemiology features of HBV/HDV co-infection in Kyrgyzstan. Infektsiya i immunitet = Russian Journal of Infection and Immunity, 2016, vol. 6, no. 2, pp. 141-150. doi: 10.15789/2220-7619-2016-2-141-150(In Russ.)]

8. Шайзадина Ф.М., Кошерова Б.Н., Омарова А.О. Эпидемический процесс вирусного гепатита В на территории Северо-Казахстанской области // Журнал инфектологии. 2016. Т. 8, № 3. С. 123-124. [Shayzadina F.M., Kosherova B.N., Omarov A.O. The epidemic process of viral hepatitis B in the territory of the North Kazakhstan region. Zhurnal infektologii = Journal of Infectology, 2016, vol. 8, no. 3, pp. 123-124. (In Russ.)]

9. Шевцов А.Б., Филипенко М.Л., Киянбекова Л.С., Кравченко А.П., Омралина А.Е., Абеев А.Б., Мухамедьяров Д.А., Раманкулов Е.М. Генотипы вируса гепатита В, циркулирующие на территории г. Астана // Биотехнология. Теория и практика. 2011. № 4. С. 14-23. [Shevtsov A.B., Filipenko M.L., Kiyanbekova L.S., Kravchenko A.P., Omralina A.E., Abeev A.B., Mukhamedyarov D.A., Ramankulov E.M. Genotypes of the hepatitis B virus, circulating in the territory of Astana. Biotekhnologiya. Teoriya i praktika = Biotechnology. Theory and Practice, 2011, no. 4, pp. 14-23. (In Russ.)]

10. Alavian S.M. Occult hepatitis B virus infection among hemodialysis patients. Hepat. Mon., 2012, vol. 12, no 4, pp. $242-243$. doi: 10.5812/hepatmon.869

11. Arauz-Ruiz P., Norder H., Robertson B.H., Magnius L.O. Genotype H: a new Amerindian genotype of hepatitis B virus revealed in Central America. J. Gen. Virol., 2002, vol. 83, no. 8, pp. 2059-2073. doi: 10.1099/0022-1317-83-8-2059

12. Baumert T.F., Thimme R., von Weizsäcker F. Pathogenesis of hepatitis B virus infection. World J. Gastroenterol., 2007, vol. 13, no. 1, pp. 82-90. doi: 10.3748/wjg.v13.i1.82

13. Beasley R.P., Hwang L.Y., Lee G.C., Lan C.C., Roan C.H., Huang F.Y., Chen C.L. Prevention of perinatally transmitted hepatitis B virus infections with hepatitis B virus infections with hepatitis B immune globulin and hepatitis B vaccine. Lancet, 1983, vol. 2 (8359), pp. 1099-1102.

14. Bes M., Vargas V., Piron M., Casamitjana N., Esteban J. I., Vilanova N., Pinacho A., Quer J., Puig L., Guardia J., Sauleda S. T cell responses and viral variability in blood donation candidates with occult hepatitis B infection. J. Hepatol., 2012, vol. 56, no. 4, pp. 765-774. doi: 10.1016/j.jhep.2011.11.011

15. Bissinger A.L., Fehrle C., Werner C.R., Lauer U.M., Malek N.P., Berg C.P. Epidemiology and genotyping of patients with chronic hepatitis b: genotype shifting observed in patients from Central Europe. Pol. J. Microbiol., 2015, vol. 64, no. 1, pp. $15-21$.

16. Brichler S., Lagathu G., Chekaraou M.A., Le Gal F., Edouard A., Dény P., Césaire R., Gordien E. African, Amerindian and European hepatitis B virus strains circulate on the Caribbean Island of Martinique. J. Gen. Virol., 2013, vol. 94, iss. 10, pp. 23182329. doi: 10.1099/vir.0.055459-0

17. De Mitri M.S., Cassini R., Bernardi M. Hepatitis B virus-related hepatocarcinogenesis: molecular oncogenic potential of clear or occult infections. Eur. J. Cancer., 2010, vol. 46, pp. 2178-2186. doi: 10.1016/j.ejca.2010.03.034

18. Dufour D.R. Hepatitis B surface antigen (HBsAg) assays-are they good enough for their current uses? Clin. Chem., 2006, vol. 52, no. 8, pp. 1457-1459. doi: 10.1373/clinchem.2006.072504

19. Global, regional, and national age-sex specific all-cause and cause-specific mortality for 240 causes of death, 1990-2013: a systematic analysis for the Global Burden of Disease Study 2013. GBD 2013 Mortality and Causes of Death Collaborators. Lancet, 2015, vol. 385, no. 385 (9963), pp. 117-171. doi: 10.1016/S0140-6736(14)61682-2

20. Hui C. K., Sun J., Au W.Y., Lie A.K., Yueng Y.H., Zhang H.Y., Lee N.P., Hou J.L., Liang R., Lau G.K. Occult hepatitis B virus infection in hematopoietic stem cell donors in a hepatitis B virus endemic area. J. Hepatol., 2005, vol. 42, iss. 6, pp. 813-819. doi: $10.1016 /$ j.jhep.2005.01.018

21. Hyams K.C. Risks of chronicity following acute hepatitis B virus infection: a review. Clin. Infect. Dis., 1995, vol. 20, no. 4, pp. 992-1000.

22. Jeantet D., Chemin I., Mandrand B., Tran A., Zoulim F., Merle P., Trepo C., Kay A. Cloning and expression of surface antigens from occult chronic hepatitis B virus infections and their recognition by commercial detection assays. J. Med. Virol., 2004, vol. 73, iss. 4, pp. 508-515. doi: 10.1002/jmv.20119

23. Jutavijittum P., Andernach I.E, Yousukh A., Samountry B., Samountry K., Thammavong T., Keokhamphue J., Toriyama K., Muller C.P. Occult hepatitis B infections among blood donors in Lao PDR. Vox. Sang., 2014, vol. 106, iss. 1, pp. 31-37. doi: 10.1111/ vox. 12073

24. Kao J.-H. Molecular epidemiology of hepatitis B virus. Korean J. Intern. Med., 2011, vol. 26, no. 3, pp. 255-261. doi:10.3904/ kjim.2011.26.3.255 
25. Kramvis A., Paraskevis D. Subgenotype A1 of HBV - tracing human migrations in and out of Africa. Antivir. Ther., 2013, vol. 18 (3 B), pp. 513-521. doi: 10.3851/IMP2657

26. Kumar S., Stecher G., Tamura K. MEGA7: molecular evolutionary genetics analysis version 7.0 for bigger datasets. Mol. Biol. Evol., 2016, vol. 33, iss. 7, pp. 1870-1874. doi: 10.1093/molbev/msw054

27. Lin C.-L., Kao J.-H. Hepatitis B virus genotypes and variants. Cold Spring Harb. Perspect. Med., 2015, vol. 5, no. 5:a021436. doi: 10.1101/cshperspect.a021436

28. Margolis H.S., Alter M.J., Hadler S.C. Hepatitis B: evolving epidemiology and implications for control. Semin. Liver Dis., 1991, vol. 11, no. 2, pp. 84-92. doi: 10.1055/s-2008-1040427

29. McMahon B.J., Alward W.L., Hall D.B., Heyward W.L., Bender T.R., Francis D.P., Maynard J.E. Acute hepatitis B virus infection: relation of age to the clinical expression of disease and subsequent development of the carrier state. J. Infect. Dis., 1985, vol. 151, no. 4, pp. 599-603.

30. Mulrooney-Cousins P.M, Michalak T.I. Persistent occult hepatitis B virus infection: experimental findings and clinical implications. World J. Gastroenterol., 2007, vol. 13, no. 43, pp. 5682-5686. doi: 10.3748/wjg.v13.i43.5682

31. Norder H., Couroucé A.M., Coursaget P., Echevarria J.M., Lee S.D., Mushahwar I.K., Robertson B.H., Locarnini S., Magnius L.O. Genetic diversity of hepatitis B virus strains derived worldwide: genotypes, subgenotypes, and HBsAg subtypes. Intervirology, 2004, vol. 47, no. 6, pp. 289-309. doi: 10.1159/000080872

32. Nurgalieva Z.Z., Hollinger F.B., Graham D.Y., Zhangabylova S., Zhangabylov A. Epidemiology and transmission of hepatitis B and C viruses in Kazakhstan. World J. Gastroenterol., 2007, vol. 13, no. 8, pp. 1204-1207. doi: 10.3748/wjg.v13.i8.1204

33. Okamoto H., Tsuda F., Sakugawa H., Sastrosoewignjo R.I., Imai M., Miyakawa Y., Mayumi M. Typing hepatitis B virus by homology in nucleotide sequence: comparison of surface antigen subtypes. J. Gen. Virol., 1988, vol. 69, pp. 2575-2583. doi: 10.1099/0022 1317-69-10-2575

34. Oluyinka O.O., Tong H.V., Bui Tien S., Fagbami A.H., Adekanle O., Ojurongbe O., Bock C.T., Kremsner P.G., Velavan T.P. Occult Hepatitis B Virus Infection in Nigerian Blood Donors and Hepatitis B Virus Transmission Risks. PLoS One, 2015, vol. 10, no. 7:e0131912. doi: 10.1371/journal.pone.0131912

35. Pisano M.B., Blanco S., Carrizo H., Ré V.E., Gallego S. Hepatitis B virus infection in blood donors in Argentina: prevalence of infection, genotype distribution and frequency of occult HBV infection. Arch. Virol., 2016, vol. 161, no. 10, pp. $2813-2817$. doi: 10.1007/s00705-016-2960-2

36. Pollicino T., Squadrito G., Cerenzia G., Cacciola I., Raffa G., Craxi A., Farinati F., Missale G., Smedile A., Tiribelli C., Villa E., Raimondo G. Hepatitis B virus maintains its pro-oncogenic properties in the case of occult HBV infection. Gastroenterology, 2004, vol. 126, iss. 1, pp. 102-110. doi: 10.1053/j.gastro.2003.10.048

37. Poorolajal J., Majdzadeh R. Prevalence of chronic hepatitis B infection in Iran: a review article. J. Res. Med. Sci., 2009, vol. 14, no. 4, pp. 249-258.

38. Pourkarim M.R., Lemey P., Amini-Bavil-Olyaee S., Houspie L., Verbeeck J., Rahman M., Maes P., Vanwijngaerden E., Nevens F., Van Ranst M. Molecular characterization of hepatitis B virus strains circulating in Belgian patients co-infected with HIV and HBV: Overt and occult infection. J. Med. Virol., 2011, vol. 83, iss. 11, pp. 1876-1884. doi: 10.1002/jmv.22174

39. Raimondo G., Allain J.P., Brunetto M.R., Buendia M.A., Chen D.S., Colombo M., Craxi A., Donato F., Ferrari C., Gaeta G.B., Gerlich W.H., Levrero M., Locarnini S., Michalak T., Mondelli M.U., Pawlotsky J.M., Pollicino T., Prati D., Puoti M., Samuel D., Shouval D., Smedile A., Squadrito G., Trepo C., Villa E., Will H., Zanetti A.R., Zoulim F. Statements from the Taormina expert meeting on occult hepatitis B virus infection. J. Hepatol., 2008, vol. 49, iss. 4, pp. 652-657. doi: 10.1016/j.jhep.2008.07.014

40. Sarkar N., Pal A., Das D., Saha D., Biswas A., Bandopadhayay B., Chakraborti M., Ghosh M., Chakravarty R. Virological characteristics of acute hepatitis B in Eastern India: critical differences with chronic infection. PLoS One, 2015, vol. 10, no. 11: e0141741. doi: 10.1371/journal.pone.0141741

41. Shapiro C.N. Epidemiology of hepatitis B. Pediatr. Infect. Dis. J., 1993, vol. 12, no. 5, pp. 433-437.

42. Smolle E., Zohrer E., Bettermann K., Haybaeck J. Viral hepatitis induces hepatocellular cancer: what can we learn from epidemiology comparing Iran and worldwide findings? Hepat. Mon., 2012, vol. 12 (10 HCC):e7879. doi: 10.5812/hepatmon.7879

43. Tallo T., Tefanova V., Priimagi L., Schmidt J., Katargina O., Michailov M., Mukomolov S., Magnius L., Norder H. D2: major subgenotype of hepatitis B virus in Russia and the Baltic region. J. Gen. Virol., 2008, vol. 89, iss. 8, pp. 1829-1839. doi: 10.1099/ vir.0.83660-0

44. Thedja M.D., Roni M., Harahap A.R., Siregar N.C., Ie S.I., Muljono D.H. Occult hepatitis B in blood donors in Indonesia: altered antigenicity of the hepatitis B virus surface protein. Hepatol. Int., 2010, vol. 4, no. 3, pp. 608-614. doi: 10.1007/s12072-010-9203-5

45. Thompson J.D. Higgins D. G., Gibson T. J. CLUSTAL W: improving the sensitivity of progressive multiple sequence alignment through sequence weighting, position-specific gap penalties and weight matrix choice. Nucleic Acids Res., 1994, vol. 22, no. 22, pp. 4673-4680.

46. Vaezjalali M., Rashidpour S., Rezaee H., Hajibeigi B., Zeidi M., Gachkar L., Aghamohamad S., Najafi R., Goudarzi H. Hepatitis B viral DNA among HBs antigen negative healthy blood donors. Hepat. Mon., 2013, vol. 13, no. 3:e6590. doi: 10.5812/hepatmon.6590

47. World Health Organization. Prevention and control of viral hepatitis infection: frame work for global action. Geneva: WHO, 2012. URL: http://www.who.int/hiv/pub/hepatitis/Framework/en/(13.12.2017)

48. Yuen M.F., Lai C.L. Hepatitis B virus genotypes: natural history and implications for treatment. Expert. Rev. Gastroenterol. Hepatol., 2007, vol. 1, pp. 321-328. doi: 10.1586/17474124.1.2.321 
49. Yim H.J., Lok A.S. Natural history of chronic hepatitis B virus infection: what we knew in 1981 and what we know in 2005. Hepatol., 2006, vol. 43, iss. S1, pp. S173-S181. doi: 10.1002/hep.20956

50. Zerbini A., Pilli M., Boni C., Fisicaro P., Penna A., Di V. P., Giuberti T., Orlandini A., Raffa G., Pollicino T., Raimondo G., Ferrari C., Missale G. The characteristics of the cell-mediated immune response identify different profiles of occult hepatitis B virus infection. Gastroenterology, 2008, vol. 134, iss. 5, pp. 1470-1481. doi: 10.1053/j.gastro.2008.02.017

\section{Авторы:}

Останкова Ю.В., научный сотрудник лаборатории молекулярной иммунологии ФБУН НИИ эпидемиологии и микробиологии имени Пастера, Санкт-Петербург, Россия; Семенов А.В., к.б.н., зав. лабораторией вирусологии и иммунологии ВИЧ-инфекции ФБУН НИИ эпидемиологии и микробиологии имени Пастера, Санкт-Петербург, Россия; доцент кафедры иммунологии ГБОУ ВПО Первый СанктПетербургский Государственный медицинский университет им. акад. И.П. Павлова МЗ РФ, Санкт-Петербург, Россия; доцент кафедры клинической лабораторной диагностики ГБОУ ВПО Северо-Западный государственный медицинский университет им. И.И. Мечникова МЗ РФ, Санкт-Петербург, Россия;

Буркитбаев Ж.К., к.м.Н., директор Научно-производственного центра трансфузиологии, Астана, Республика Казахстан; Савчук Т.Н., зав. отделением лабораторных исследований трансфузионных инфекций, РГП на ПХВ Научнопроизводственного центра трансфузиологии, Астана, Республика Казахстан;

Тотолян Арег А., академик РАН, д.м.н., профессор, зав. лабораторией молекулярной иммунологии, директор ФБУН НИИ эпидемиологии и микробиологии имени Пастера, Санкт-Петербург, Россия; зав. кафедрой иммунологии ГБОУ ВПО Первый Санкт-Петербургский Государственный медицинский университет им. акад. И.П. Павлова МЗ РФ, Санкт-Петербург, Россия.

\author{
Authors: \\ Ostankova Ju.V., Researcher, Laboratory of Molecular \\ Immunology, St. Petersburg Pasteur Institute, St. Petersburg, \\ Russian Federation; \\ Semenov A.V., PhD (Biology), Head of the Laboratory \\ of Virology and Immunology HIV, St. Petersburg Pasteur Institute, \\ St. Petersburg, Russian Federation; Associate Professor, Pavlov \\ First St. Petersburg State Medical University, St. Petersburg, \\ Russian Federation; Associate Professor, Department of Clinical \\ Laboratory Diagnostics, North-West State Medical University named \\ after I.I. Mechnikov, St. Petersburg, Russian Federation; \\ Burkitbayev Z.K., PhD (Medicine), Director of Research- \\ Production Center of Transfusiology, Astana, Kazakhstan Republic; \\ Savchuk T.N., Head of Department of Laboratory Studies \\ of Transfusion Infections, Research-Production Center \\ of Transfusiology, Astana, Kazakhstan Republic; \\ Totolian Areg A., RAS Full Member, PhD, MD (Medicine), \\ Professor, Head of the Laboratory of Molecular Immunology, \\ Director of St. Petersburg Pasteur Institute, St. Petersburg, Russian \\ Federation; Head of the Department of Immunology, Pavlov First \\ St. Petersburg State Medical University, St. Petersburg, Russian \\ Federation.
}

